\title{
Підвищення енергоефективності багатозональних VRF систем кондиціювання повітря
}

\author{
Н. В. Жихарєва ${ }^{\bowtie}$, С. О. Бабой, А. М. Басов \\ Одеська національна академія харчових технологій, вул. Канатна, 112, Одеса, 65039, Україна \\ $\triangle$ e-mail: zhikhareva.nata@gmail.com
}

\begin{abstract}
Визначено енергозберігаючі заходи підвищення енергоефективності в області кондиціювання за допомогою методів математичного моделювання схемно-технічних рішень і режимів роботи обладнання систем кондииіювання громадських об'єктів при використанні сучасних VRF систем. Розроблена комплексна модель оптимізації систем кондиціювання громадських об'єктів. Ця модель враховує не тільки нестаціонарне зовнішнє $i$ внутрішнє теплове навантаження в приміщенні, але також і фактори по мінімізації змінної частини наведених витрат, пов'язаних з витратами енергії. Протестована иільова функиія оптимізації спільної сумарної величини капітальних і експлуатаційних витрат на тепловий захист приміщень $і$ кліматичне енергозберігаюче обладнання протягом терміну їх експлуатації із забезпеченням наймениих приведених витрат. Можливості енергозбереження проведені при розрахунку універсальної цільової функції та програм математичного моделювання щзодо визначення термінів окупності та величин цүільової функиії для порівнюваних варіантів. Проведений порівняльний аналіз на базі розробленої математичної моделі Daikin, Mitsubishi Electric, Fujitsu, Mitsubishi Heavy для об'єктів, які працюють протягом добового циклу в екстремально-нестаціонарному режимі. До таких об'єктів громадського призначення можна віднести театри, ресторани, заводські їдальні, конференц-зали тощзо. При розрахунках за изією моделлю можна отримати термін окупності обладнання із застосуванням економічно-доцільної товщчини ізоляції.
\end{abstract}

Ключові слова: енергоефективність, оптимізація, кондиціювання повітря, енергозбереження, ціільова функція, моделювання, теплообмін

(C) The Author(s) 2018. This article is an open access publication

This work is licensed under the Creative Commons Attribution 4.0 International License (CC BY) http://creativecommons.org/licenses/by/4.0/

\section{1. Вступ}

В умовах прискорення науково-технічного прогресу завдання підвищення енергоефективності систем кондиціювання має важливе народногосподарське значення, оскільки ії рішення, крім підвищення ефективності капітальних вкладень, забезпечує іiї енергозбереження, економію матеріалів, а також поліпшення умов праці людей і навколишнього середовища.

Огляд методів енергозбереження в системах вентиляції та кондиціювання через масштабність проблеми ставить технікоекономічну задачу, рішення якої може бути корисним при проектуванні $[1,2,3,4]$.

Проектування систем кондиціювання повітря потребує системного аналізу та синтезу із застосуванням методів математичного моделювання. Для цього систему кондиціювання повітря підрозділяють на підсистеми й окремі елементи, для яких потім здійснюють кількісний аналіз на основі математичних моделей підсистем.

Одним з основних завдань цієї комплексної проблеми є енергозбереження. Ми вирішуємо триєдину проблему - оптимізацію (мінімізацію) енергоспоживання при жорсткому дотриманні нормативних вимог до комфортного середовища проживання в житлових, громадських і промислових об'єктах, неухильне дотримання технологічних вимог у виробничих процесах $\mathrm{i}$ мінімізацію шкідливого впливу на екологію навколиш- нього середовища. Декомпозиція як єдиної енергетичної системи представляється трьома основними енергетично взаємопов'язаними підсистемами $[2,3,5,6]$.

У даній статті, використовуючи основні принципи моделювання, визначено енергозберігаючі заходи підвищення енергоефективності в області кондиціювання за допомогою методів математичного моделювання схемно-технічних рішень і режимів роботи обладнання систем кондиціювання громадських об'єктах при використанні сучасних VRF систем.

\section{2. Основні цільові напрями вдосконалення ба- гатозональних VRF систем кондиціювання по- вітря}

В роботі [1] показано парадокси традиційної методики розрахунку VRF систем кондиціювання повітря i недоцільність.

3 урахуванням підходу до моделювання енергоефективних систем [2] ми розглядаємо шляхи підвищення ефективності багатозональних систем кондиціювання.

Основними цільовими напрямами вдосконалення багатозональних систем кондиціювання останнім часом $€$ такі:

- підвищення комфорту мікроклімату об'єкта, точність і надійність його забезпечення при цілорічної експлуатації; 
- підвищення енергоефективності багатозональних систем за рахунок збільшення коефіцієнтів трансформації тепла;

- підвищення показників енергозбереження за рахунок рекуперації та акумуляції теплової енергії і постійного автоматичного оптимального управління режимами роботи, в залежності від сезонних параметрів зовнішнього повітря, сонячної радіації і геотермальних джерел тепла, а також внутрішніх нестаціонарних джерел тепло припливів / тепловтрат і джерела зміни вологості внутрішнього повітря;

- зниження шкідливого впливу на екологію навколишнього середовища;

- вдосконалення основних агрегатів багатозональної системи кондиціювання повітря: компресора, вентилятора, рекуператора, теплообмінника;

- акумулятор теплоти з використанням тепла фазового переходу, системи управління;

-інтеграція багатозональних систем с, сонячними колекторами, системою припливно-витяжної вентиляції;

- легкість інтеграції з системою «розумного будинку» (BMS з протоколами BACnet або LONwork, порти SC-LGW або SC-BGW);

- перевірочні розрахунки з розробкою монтажної схеми і повної специфікації;

- розробка віддаленого управління і комп'ютерної системи централізованого управління, узгодженого в необхідних випадках 3 пріоритетом індивідуального управління.

Необхідно відзначити, що енергозбереження найбільш ефективно, якщо воно проводиться на всіх стадіях життєвого циклу об'єкта. від вибору на етапі проектування кліматичного обладнання та величини теплового опору огороджень, опрацювання доцільності використання поновлюваних джерел енергії (ВДЕ), об'єктивного і висококваліфікованого енергоаудиту за результатами першого року експлуатації і енергоменеджменту до моменту капітальної модернізації об'єкта або його повної зупинки перед утилізацією обладнання $[2,3]$.

3 огляду на вищевикладене, нами протестована наступна цільова функція спільної оптимізації теплового захисту об'єкта (теплового опору огороджень приміщення), в якому забезпечується заданий мікроклімат, i продуктивності енергозберігаючого кліматичного обладнання активної системи забезпечення цього мікроклімату. 3 огляду на особливості оптимізації систем кондиціювання повітря $[3,7]$ пропонована цільова функція (Ptf - target function) для спільної оптимізації дозволяє визначати 3 урахуванням можливої зміни вартості електроенергії та коефіцієнта дисконтування валюти [7]

$$
\operatorname{Prf}=\min \left[\Delta P s t+P e s o b-\sum_{i=1}^{T} \frac{\Delta Q g}{(1+d-R)^{i}}\right],
$$

де $\Delta P \mathrm{st}$ - додаткова вартість утеплення зовнішніх огороджень $з$ метою посилення теплового захисту приміщень із заданим мікрокліматом (це може бути одна зовнішня стіна або всі стіни - зовнішні стіни для окремо розташованого об'єкта);

$P$ esob - витрати на покупку і установку в систему енергозберігаючого обладнання; $i$ - номер року після введення в експлуатацію енергозберігаючого обладнання;

$\Delta \mathrm{Qg}$ - річна економія вартості споживаної електроенергії в результаті використання енергозберігаючого обладнання і посилення теплозахисту об'єкта (розраховується за середньомісячною температурою зовнішнього середовища), кВт;

$d$-річний коефіцієнт дисконтування національної валюти

$R$ - коефіцієнт річного зростання вартості (кВт·год).

pel - вартість кВт години електроенергії з ПДВ.

Цільова функція (1), що визначається для заданих варіантів за допомогою програми, виконаної в обчислювальному середовищі Mathcad, дозволяє виконати спільний оптимальний вибір варіанта теплового захисту об'єкта і комплекту енергозберігаючого обладнання.

За результатами додаткового математичного моделювання, з урахуванням фактичних витрат енергії за перший рік роботи, можуть бути прийняті рекомендації, наприклад, по установці додаткового енергозберігаючого обладнання, посилення теплоізоляції огороджень, скорочення періоду між чистками фільтра і т. д.

Термін розрахункової експлуатації $T=7$ років пропонується для подальшого обговорення. Прийнято вважати, що термін окупності енергозберігаючого обладнання, дорівнює терміну гарантії на це обладнання 2-4 роки, а термін отримання прибутку після терміну окупності, що дорівнює початковим інвестиціям в енергозберігаючі заходи, з урахуванням коефіцієнта дисконтування в межах 3-5 років. Використовувати термін служби на обладнання вентиляції та кондиціювання 15-20 років, наведений в ДБН В.2.5-67: 2013, в цільової функції (1) нераціонально.

\section{3. Оптимізаційна модель СКП}

Проектування систем кондиціювання повітря потребує системного аналізу та синтезу з застосуванням методів математичного моделювання. Для цього систему кондиціювання повітря підрозділяють на підсистеми й окремі елементи, для яких потім здійснюють кількісний аналіз на основі математичних моделей підсистем.

Декомпозиція як єдиної енергетичної системи представляється трьома основними енергетично взаємопов'язаними підсистемами $[2,3,5,6]$.

Основними рівняннями моделі є рівняння балансу повітря, повної теплоти $(Q)$, вологи $(W)$, газів $(M)$ і явної теплоти $(Q я)$ в приміщенні $[4,6]$ :

$$
\begin{gathered}
G_{n 1}+G_{Y 1}-G_{p}+\sum_{i=2}^{n} G_{n i}-\sum_{j=2}^{m} G_{y j}=0 \\
G_{n 1} \cdot h_{n 1}-G_{y 1} h_{y 1}-G_{p} h_{p}+\sum_{i=2}^{n} G_{n i} h_{n i}-\sum_{j=2}^{m} G_{y j} h_{y j}+\Delta Q+\Delta Q^{\prime}=0 \\
G_{n 1} d_{n 1}-G_{y 1} d_{y 1}-G_{p} d_{p}+\sum_{i=2}^{n} G_{n i} d_{n i}-\sum_{j=2}^{m} G_{y j} d_{y j}+\Delta W+\Delta W^{\prime}=0 \\
G \frac{\chi_{\mathrm{n} 1}}{\rho_{\mathrm{n} 1}}-G_{y 1} \frac{\chi_{y 1}}{\rho_{y 1}}-G_{p} \frac{\chi_{p}}{\rho_{p}}+\sum_{i=2}^{n} G_{n i} \frac{\chi_{n i}}{\rho_{n i}}-\sum_{j=2}^{m} G_{y j} \frac{\chi_{y j}}{\rho_{y j}}+M_{\Gamma}=0
\end{gathered}
$$




$$
\begin{aligned}
& C p G_{n 1} t_{n 1}-C p G_{y 1} t_{y 1}-C p G_{p} t_{p}+ \\
& +C p \sum_{i=2}^{n} G_{n i} t_{n i}-C p \sum_{j=2}^{m} G_{y j} t_{y j}+\Delta Q я+\Delta Q^{\prime}=0
\end{aligned}
$$

де $G_{\text {п }}, G_{\mathrm{y}}, G_{\mathrm{p}}-$ витрати повітря припливного, повітря, що видаляється, та рециркуляційного повітря кг/с; $h_{\text {п }}, h_{\mathrm{y}}$ $h_{\mathrm{p}}$ - ентальпія повітря припливного, повітря, що видаляється, та рециркуляційного повітря кДж/кг; $d_{\text {п }}, d_{\mathrm{y}}, d_{\mathrm{p}}$ вологовміст повітря припливного, повітря, що видаляється, та рециркуляційного повітря; $t_{\text {п }}, t_{\mathrm{y}}, t_{\mathrm{p}}$ - температура повітря припливного, повітря, що видаляється, та рециркуляційного повітря: $x / p_{\text {п }} x / p_{\text {у }} x / p_{\mathrm{p}},-$ концентрація та густина повітря припливного, повітря, що видаляється, та рециркуляційного повітря; $\Delta G_{\mathrm{m}}, \Delta Q_{\mathrm{M}}, \Delta \mathrm{W}_{\mathrm{M}}$, $\Delta M_{\text {гм }}, \Delta Q_{\text {ям }}$ - де баланси місцевої вентиляції по повітрю, повній теплоті, волозі, газам і явній теплоті.

На першому етапі оптимізується структура й продуктивність система кондиціювання повітря, характер і навантаження.

На другому етапі здійснюється оптимізація підсистем за різними технологічними і конструктивними параметрами.

Нарешті, на третьому етапі базові варіанти структури й продуктивності систем кондиціювання повітря оптимізується разом 3 оптимальними варіантами підсистем. При цьому розраховуються річні витрати холоду систем кондиціювання повітря.

Нами розглянуті деякі технології і елементи, вдосконалення яких безпосередньо підвищує енергоефективність і знижує споживання електроенергії в річному циклі використання багатозональних систем кондиціювання. Цікава робота [2], виконана на основі енергетичних балансів теплофізичних процесів в VRF. Однак на стадії узгодження контракту, коли для обгрунтування кошторису робіт треба зробити попередній вибір, ми побудували нашу методику експериментального аналізу для вибору моделі зовнішнього блоку VRF на підставі таблиць 3 використанням формули (2) і при обліку нестаціонарного теплообміну в приміщеннях [5].

Необхідно також відзначити постійну роботу провідних світових фірм, які виробляють багатозональні системи кондиціювання, над системами їх управління та програмним забезпеченням, над полегшенням їх експлуатації та використанням таймерів, що настроюються на тривалий термін по запрограмованій автоматичній підтримці зміни параметрів мікроклімату в процесі добового, тижневого, а іноді і більш тривалого періоду.

\section{4. Результати досліджень}

Проведені розрахунки показали поєднання зовнішніх блоків при конфігуруванні модулів багатозональних систем кондиціювання, що дозволяе отримати системи холодо- і теплопродуктивності від 10 до 180 кВТ в одному модулі і підібрати оптимальну. Фірми пропонують варіанти найбільш компактних і найбільш енергоефективних модулів. Модульний принцип залишає можливість творчої оптимізації багатозональних систем кондиціювання, починаючи 3 етапу проектування, 3 урахуванням всіх особливостей конкретного об'єкта. Для цього використовуються програми-конфігуратори, які безперервно вдосконалюються.
Як правило, VRF-системи кондиціювання застосовуються в приміщеннях, де коефіцієнт неодночасності $k<1$. Тобто основний принцип функціонування мультизональних систем перерозподіл холодоагенту між споживачами з неодночасним навантаженням припускає доцільність їх використання тільки при значеннях $k<1$. За умови одночасного максимуму теплових навантажень в приміщеннях, оптимальним є застосування менш складних систем.

Тому при проектуванні VRF-систем необхідно вибирати внутрішні блоки в межах однієї системи 3 неодночасними максимумами навантажень, наприклад орієнтування по різних фасадах будівлі. Такий вибір призводить до рівномірного завантаження зовнішнього блоку протягом доби і меншій розрахунковій потужності зовнішнього блоку.

Коефіцієнт неодночасності $k$ залежить в першу чергу від теплового режиму будівлі, але не може бути менше певних величин, залежних від конструкції VRF-систем. Тому для визначення потужності зовнішнього блоку необхідно знати три величини: суму максимальних теплоприпливів обслуговуваних приміщень, суму номінальних потужностей внутрішніх блоків, коефіцієнт неодночасності теплоприпливів приміщень.

Особливістю систем автоматичного регулювання VRF-систем $є$ підтримка певного тиску на виході і вході зовнішнього блоку (рисунок 1). Втрати тиску в системі також залежать від витрати фреону $G_{\text {нар }}$ і гідравлічної характеристики мережі $k_{\text {гидр: }}$ :

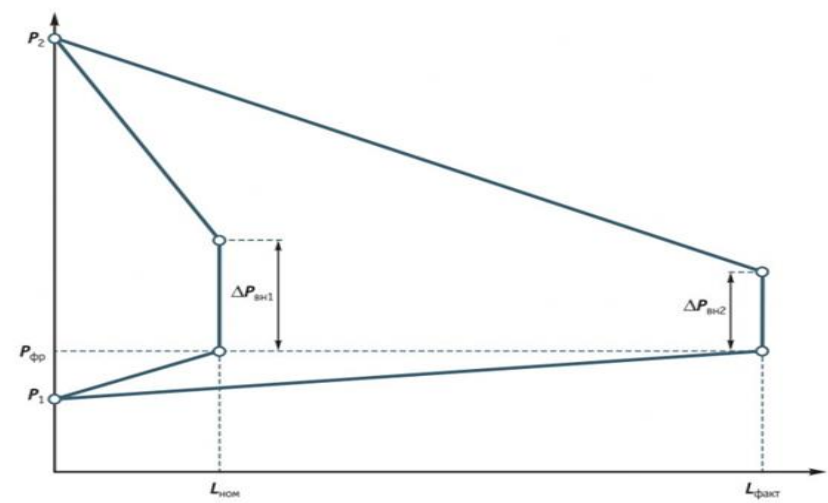

Рисунок 1 - Графік змінення тиску в нагнітаючому і всмоктуючому фреонопроводі

Таким чином, при збільшенні довжини магістралей вище за номінал 7,5 метрів відбувається збільшення гідравлічної характеристики мережі і, відповідно, зменшення витрати фреону в системі.

Пропорційно зменшенню витрати фреону (16) відбувається зменшення потужності зовнішнього блоку (рисунок 1).

Наша методика розглянута на прикладі світових лідерів в секторі виробництва обладнання: Daikin, Mitsubishi Electric, Fujitsu, Mitsubishi Heavy, де визначено найбільш ефективне обладнання. При цьому розраховувалося споживання енергії і термін окупності, залежність енергетичної ефективності роботи багатозональної системи від сумарного індексу в підключених внутрішніх блоках, залежність фактичної холодопро- 
дуктивності від сумарного індексу (сумарної номінальної холодопродуктивності підключених внутрішніх блоків), gg та інше (рисунки 2, 3).

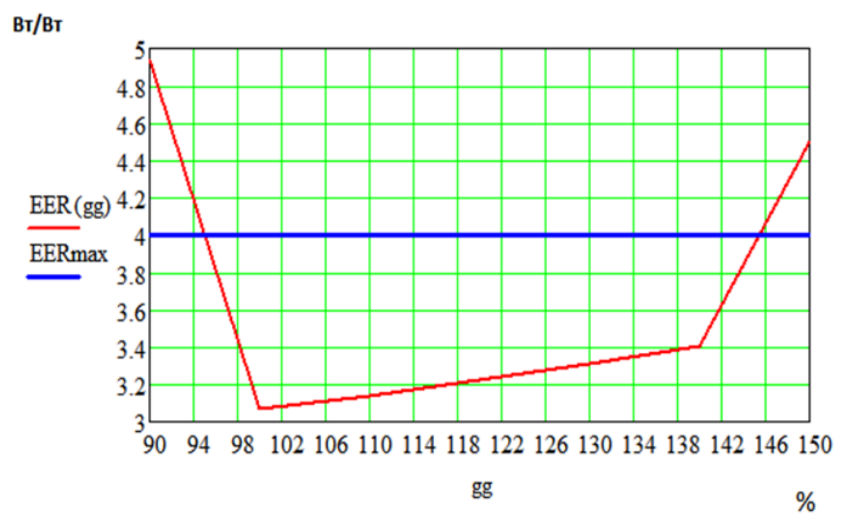

Рисунок 2 - Залежність енергетичної ефективності роботи багатозональної системи від сумарного індексу (сумарної номінальної холодопродуктивності у відсотках) в підключених внутрішніх блоках

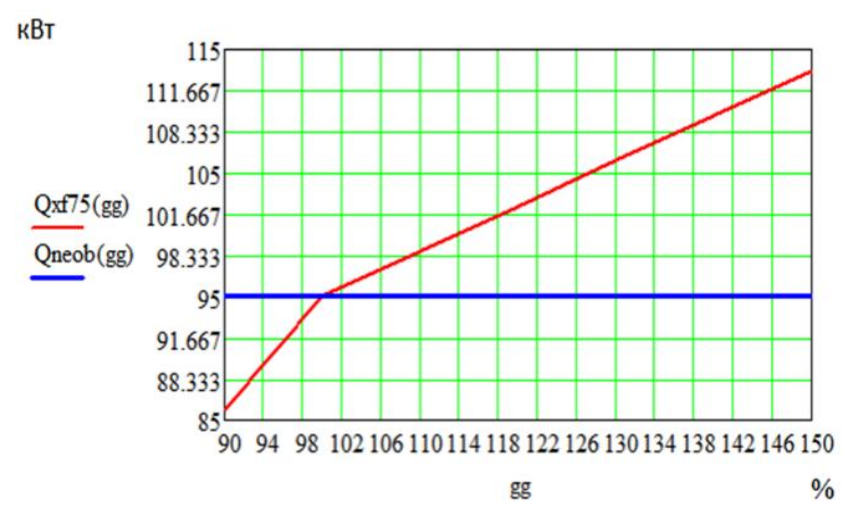

Рисунок 3 - Залежність фактичної холодопродуктивності від сумарного індексу (сумарної номінальної холодопродуктивності підключених внутрішніх блоків) $\mathrm{gg}, \%$.

\section{Висновок}

Розроблена комплексна математична модель 3 використанням отриманої цільової функції для приміщень містить принципово новий підхід до вибору оптимального кліматичного обладнання для підтримки комфортних параметрів. Ці заходи об'єднує те, що для їх реалізації, як правило, потрібні додаткові капіталовкладення. Для швидкої оцінки термінів окупності альтернативних і доповнення існуючих варіантів енергозберігаючих заходів потрібна наявність програмного інструментарію не тільки 3 дружнім інтерфейсом, але i імперативними обмеженнями по всіх параметрах мікроклімату в даному об'єкті відповідно до чинних нормативних документів.

При підборі обладнання враховується вплив чинників (мінлива температура холодоагенту, інверторний привід, рекуперація) та параметрів обладнання (компресор, вентилятор, теплообмінники, фільтри.)

Враховуючи ці фактори проведений експрес-аналіз для вибору моделі зовнішнього блока VRF на підставі таблиць фірм-представників та проведені розрахунки.
Розроблена оціночна методика може бути використана для спільного вибору агрегату припливно-витяжної системи кондиціювання повітря 3 рекуперацією, інверторного кондиціонера і конструкції відповідних зовнішніх огороджень на ранній стадії проектування.

Результати математичного моделювання дозволяють визначити енергоефективне обладнання багатозональних систем кондиціюванням повітря при рахуванні чинників та параметрів оптимізації. Графічне зображення залежностей фактичної потужності і холодопродуктивності від зовнішньої температури (рисунок 4) відповідає таблицями фірмових даних [3]. 3 цих рисунків також видно, що при збільшенні температури коефіцієнт енергетичної ефективності МЗС зменшується. Однак в сучасних інтелектуальних програмах управління числами оборотів компресора i температурою холодоагенту сезонне і річне споживання електроенергії буде значно нижче, ніж в системах без такого регулювання, тому сезонний коефіцієнт теплоефективності таких МЗС набагато вище.

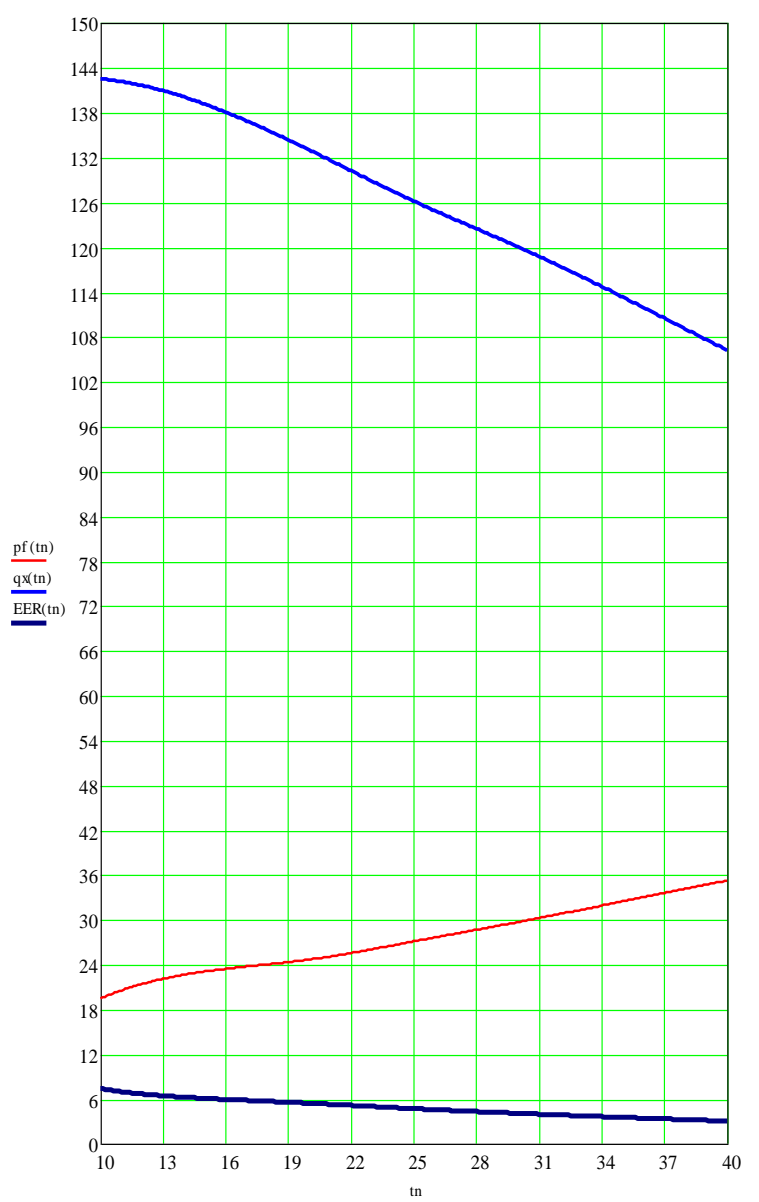

Рисунок 4 - Залежність фактичної холодовидатності $q x(t n)$, фактичній споживаній потужності $p f(t n)$ і їх відношення $\operatorname{EER}(t n)$, що визначає ефективність роботи 3C

на охолодження, від зовнішньої температури $t$.

При використанні меншого типономінала зовнішнього блоку AJYO72LALBH необхідно витрачати більшу потужність - 7 кВт замість 6,16 кВт при використанні зовнішнього блоку AJY090LALBH. Тобто цей зовнішній блок більшого типономінала при такій тем- 
пературі буде працювати з більшим СЕК = 3,636, ніж AJYO72LALBH, який в цих же умовах буде відповідати $\mathrm{EEK}=3,2$.

Зі сказаного ясно, що максимальна теплова потужність / холодопродуктивність БЗС повинна відповідати максимальним теплоприпливам або тепловтратам кондиціонером об'єкта, а річна витрата електроенергії буде залежати від досконалості обладнання, яке автоматично підтримує з необхідною точністю задані сезонні температури повітря в об'єкті, в залежності від зміни зовнішніх умов і режиму тепловиділень і волого виділення всередині об'єкта. Таке вдосконалення функціональних параметрів МЗС спільно з їх постійним вдосконаленням в частині надання більш повного комфорту користувачам, включаючи шум і відносну вологість, і вдосконалення екологічної безпеки їх роботи, є сучасним трендом розвитку кліматичної техніки.

Конкретний термін окупності БЗС із зовнішнім блоком (модулем) більшого типономінала в порівнянні 3 блоком (модулем) меншого типономінала за рахунок економії електроенергії можливо визначити за апробованою методикою розрахунку теплоприпливів і тепловтрат об'єкта протягом річного циклу для середньомісячних зовнішніх температур.

Литература
1. Табунщиков Ю. А. Математическое моделирование и оптимизация тепловой эффективности зданий. // Ю. А. Табунщиков, М. М. Бродач. - М.: АВОК-ПРЕСС. $-2002 .-194$ c.

2. Брух В. В. Парадоксы традиционной методики расчета VRF систем кондиционирования воздуха. // В. В. Брух / СОК - 2005. - № 5. - С. 62-64.

3. Перепека В. И. Расчеты систем кондиционирования и вентиляции. // В.И. Перепека, Н.В.Жихарева / Одесса: «ТЭС», 2014. - 240 с.

4. Zhykhareva N. Modeling of energy efficient air condition // N.V Zhyikharieva. / The scientific method. Poland, 2017. - No. 3. - P. 3-6.

5. Zhykhareva N. Optimization of conditioning system for fremises with non stationary heat exchanger // N. Zhyikharieva / Norwegian Journal of development of the International Science, 2017. - Vol. 2, No. 5. - P. 94-99.

6. Грачев Ю. Г. Основы оптимизации систем кондиционирования микроклимата. // Н. В. Жихарєва / Пермь, изд. Перм, политехн.ин-та, 1987 - 80 с.+ 1 вкл.

7. Жихарєва Н. В. Оптимізація сумарної вартості теплового захисту приміщень та кліматичного обладнання. // Н. В. Жихарєва, М. Г. Хмельнюк / Холодильна техніка та технологія, 2017 - Том 53, вип. 4. - С. 17-20.

Отримана в редакції 12.10.2018, прийнята до друку 04.12.2018

\title{
Increase in energy efficiency of multi-zone air conditioning systems, which provide a microclimate of public buildings all year
}

\author{
N. Zhykharieva, E. Baboi, A. Basov \\ Odessa National Academy of Food Technologies, 112 Kanatnaia str., Odessa, 65039, Ukraine
}

\begin{abstract}
Energy-saving measures to improve efficiency in the field of air conditioning are determined using methods of mathematical modeling of circuit-technical solutions and modes of operation of air-conditioning equipment for public facilities using modern multi-zonal systems. Model takes into account not only the non-stationary external and internal heat load in the room but also the factors for minimizing the variable portion of the reduced costs associated with energy costs. The goal function is to optimize the joint optimization of the total value of capital and operating costs for thermal protection of premises and climate-friendly energy-saving equipment during the period of their operation with the provision of the least adjusted costs. The energy saving capabilities were carried out in calculating the universal objective function and mathematical modeling software by determining the payback period and the objective function values for the compared options. Conducted a comparative analysis based on the developed mathematical model of Daikin, Mitsubishi Electric, Fujitsu, Mitsubishi Heavy for objects operating during the daily cycle in the extreme-non-stationary mode. Such public objects include theaters, restaurants, factory canteens, conference halls and the like. At calculations under this model it is possible to receive a payback period of the equipment with application.
\end{abstract}

Keywords: energy efficiency, optimization, air conditioning, energy saving, objective function, modeling, heat exchange

\section{References}

1. Tabunschykov, Y. A., Brodach, M. N. (2002) Matematicheskoe modelirovanie i optimizatsiia teplovoi effekkivnosti zdanii. Moskow: Avok-PRESS, 194 p. (in Russian) 2. Brukh V.V. (2005) Paradoksy traditsionnoi metodiki rascheta VRF system konditsionirovaniia vozdukha. SOK, No. 5, pp. 62-64 (in Russian)

3. Perepeka, V. I., Zhykhareva, N. V. (2014) The calculations of air conditioning and ventilation. Odessa «TEC», 240 p. (in Russian)

4. Zhykhareva N. Modeling of energy efficient air condition. The scientific method, Poland, No. 3, 3-6.

5. Zhykhareva N. (2017) Optimization of conditioning system for fremises with non stationary heat exchanger.
Norwegian Journal of development of the International Science, 2(5), 94-99.

6. Grachev Y.G. (1987) Osnovy optimizatsii system konditsionirovaniia mikroklimata. Izd. Permskogo politekhnicheskogo instituta, Perm, 80 p. (in Russian)

7. Zhykhareva N., Khmelniuk M. (1987) Buildings

Thermal Protection and Air Conditioning Equipment Overall Cost Optimization. Refrigeration Engineering and Technology, 53(4), 17-20 (in Ukrainian)

DOI: http://dx.doi.org/10.15673/ret.v53i4.706 